\title{
三菱金属新潟工場のタングステン及びモリブデン製錬
}

\author{
堀口米次郎**安田毫一**遠藤 芳 英** \\ 原田長男**安藤正久**
}

\section{Metallurgy of Tungsten and Molybdenum at Mitsubisi Niigata Plant}

Yonejiro HORIGUCHI and fore others

\begin{abstract}
Our Mitsubishi Metal Mining Company presently manufactures various powder metallurgical products; for example, Wolframite filament, Molybdenum wire and cemented tungsten carbide alloy called "Tridia". Wolframite metal, raw materials used for these products are refined from wolframite ore at our Niigata Work.

We report the history and methods of Wolframite and Molybdenum extraction in the last decade.

Quantity of production and purity of these metals have extremely increased recently. Studies on the relations between powder sizes reduced with hydrogen gas in various temperatures and sizes of tungsten-ammonium para-salt have been made.

Furthermore, we have also studied on the property of wolframite metal reduced from wolframite-para-salt of various crystal forms as per operational data.
\end{abstract}

\section{1. 緒 言}

三菱金属鉱業株式会社新潟工場は昭和18年 8 月設立さ れたが，建設半ばで終戦となり，戦後戦争中の事業を生 かし各種の粉末冶金製品の綜合工場として，かつ一貫作 業工場として操業今日に至つている。

1) タングステン並びにモリブデン製錬に関しては荒 川鉱業会社高取鉣山より库出する重石鈗を製鍊しタング ステン金属を製造し，これをさらに進めて超硬合金及び タングステン線を製出し，2）モリブデン鉱石を製錬し てモリブデン金属を製造し，これよりもリブデン線を製 出している。すなわち下図の通りである。

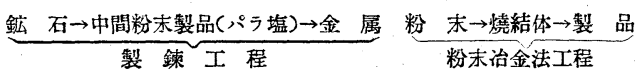

各種製鍊工程，粉末治金法工程を経て製品を作つている 訳である。したがつて鉱山に随伴して営まれる，いわゅ る製錬部門之は多少との規模，㥞式，内容等は異なるも のがある。

粉末治金工業としての原料である金属粉末の具㣁すべ き條件として，1）化学的純度が極度に高い事，特にあ る特有の元素に対してはその微量をも避ける事。2) 物 理的性質がそれぞれの目的に応じた性能を有する事，例 えば粉末の粒度分布が適当であること，形状が適当であ りかつ流動性, 圧縮性等が良好なる事, その他である。

* 三菱金属鉱業株式全社加工部長

**三三菱金属鉱業株式会社新鼬工場
これ等の 1)，2）條件苍同時に具備す心゙き金属粉末を生 革すると言う事である。

当新潟工場は一般的條件として鈗石, 原料, 資材の運 搬上の問題, 学働力, 工場用水, 電力, 燃料, 鉱害の問 題等に対しては有利な立地條件にある。すなわ方国鉄引 込線があり,学㣫源も優秀な気質足持つ新潟県人であり, すぐそばに豊富なる信濃川の水力を有し，電力も県外に 供給する状況でり，特に然料源としての天然がスの利 用をなし得られる事は極めて大きな利点である。鉣区 (採掘権) 30,000坪を有し，豊富なる天然がス（約 8,500 $\left.\mathrm{cal} / \mathrm{m}^{3}\right)$ を埋蔵しており, 現在 $600 \mathrm{~m}$ 層に 1 本, 130 $200 \mathrm{~m}$ 層に 2 本, 訫 3 本をさく井して $260 \mathrm{~m}^{3} / \mathrm{hr}$ のガス を採取し，製鍊作業はもちろん暖房にも全面的に活用し ており，照明，モーター以外はほとんぞ電気を使用して いない現状で，原価に及涩す影響は極めて大きい。

\section{2. 沿革}

（発生事情より現在末での概況）

戦争中に引続き終戦後タングステン線製造のため, 重 石鉣からタングステン金属の製錙を小規模ながら開始し た。これは当社大井工場にて生野鉣山よりの沈澱 $\mathrm{CaWO}_{\star}$ を原料として操業していたタングステン製鍊の経験が非 常に参考となつた。

第 1 期（昭和 20 年 10 月～炤和 23 年 12 月）

タングステン，モリブデン線の試作実験を行うための 
原料としてタングステンパシ塩，こリー゙デンパシ塩，タ ングステン酸等ね製造した。当時は塩酸，アンモニア水 の大手にも因難な時代で一時は直島製煉所で作つていた 余熱蒸気による塩と塔酸から塩酸を作つて貪う計画と か，硫酸による鉣石の抽出等を行つていた時代であり当 然品質的な検討わ加え得る段階ではなかつた。

第 2 期（昭和24年 1 月～昭和 25 年 3 月）

昭和23年末に抢ける大井工場の製錬部門の閉鎖に伴い この部門觉全面的に新潟工場で引継き製鍊することにな つた。昭和 5 年以来当社で高取鉣山のタングステン鉣よ り精鍊した金属タングステン觉使用し超硬合金刀製造研 究は炤和 8 年に初めて試錐用として成功し昭和17年には さらにオーガー皮びニールカッターとして成功したが戦 後は特に勒性を付与するこ之に成功し，いよいよ具体的 に穿岩機用ごットに応用し始めた。昭和 22 年以来社内鉱 山で実用試験乙昭和 24 年 1 月より新潟工場でメ゙ィヤごッ トとして本格的生産を行う事になつたので前述のタング ステン線製造の目的の他にごット用超硬合金原料のタン グステン金属をも本格的に製錬するようになつた。

第 3 期（昭和 25 年 4 月〜昭和 29 年 3 月）

ダイヤビット用テップは数度に亘る技術检討並びに笑 地試験により作業方式の確立を見, 品質も一段に向上, 安定し，生産量も遂に毎月 $800 \mathrm{~kg}$ 觉突破する状勢とな り，W線，Mo線もまた徹底的に研究検討を加元品質も 漸次向上し，受註はますます増大して来た。これに伴い 原料たる $\mathrm{W}$ パフ塩は $2,000 \mathrm{~kg} /$ 月 以上, Mo パラ塩は $200 \mathrm{~kg} /$ 月 以上の生産を行う状況となつた。

第 4 期（昭和29年 4 月～現在）

戦後の工業界心安定拡大とともに生産すれば売れる時 代は過き，競争は次第に苛烈となり品質向上，コスト引 下の必要性を痛感せらるる時期となつて来た。幸に現状 ではタングステンパフ塩約 $3,500 〜 4,000 \mathrm{~kg} /$ 月，超硬合 金テップ毎月約 $2,500 \mathrm{~kg}$ に及んでいる。その間粉末冶 金の主体原料たる W パシ塩，Mo パン塩の品質特に化 学純度の向上，パシ塩の粒度形状と還元メタルの粒度と の関連性の究明点行うとともに工程の機械化，自動化に よるコストの低減を逐次実行する事となつた。

\section{タングステン製鍊の部}

\section{3. 現在の作業方法}

前の第 2 項沿革で解るように当所 $\mathrm{W}$ 製鍊刀方式は大 井工場に抢ける生野沈搌 $\mathrm{CaWO}_{4}$ よりの Wメタルの製 鍊技術を参考と乙，これに加えて新潟工場では特にWメ タルの品位の向上，歩留の向上を目的とするため高取鉱 山の鉄マンガン重石を原料として製鍊する事となつたも のである。
鉄マンガン重石成分

\begin{tabular}{|c|c|c|c|c|c|c|c|}
\hline 試 & 料 & $\mathrm{wO}_{3}$ & $\mathrm{SiO}_{3}$ & \multicolumn{2}{|c|}{$\mathrm{Fe}_{2} \mathrm{O}_{3}$} & $\mathrm{MnO}$ & $\mathrm{CaO}$ \\
\hline & & $\begin{array}{l}73.17 \\
71.56\end{array}$ & $\begin{array}{l}1.49 \\
2.52\end{array}$ & \multicolumn{2}{|c|}{$\begin{array}{r}16.49 \\
15.502\end{array}$} & $\begin{array}{l}8.19 \\
6.663\end{array}$ & \\
\hline 詮 & 料 & 10 & $\mathrm{SnO}$ & $\mathrm{s}$ & Mo & $\mathrm{O}_{3}$ & $\mathrm{P}_{2} \mathrm{O}_{5}$ \\
\hline & & & $\begin{array}{l}0.15 \\
0.151\end{array}$ & 0.353 & $\begin{array}{l}0.007 \\
0.001\end{array}$ & 0.273 & 0.001 \\
\hline
\end{tabular}

以下工程順にこの大要死記述子る（第1図参照）。

粉砕：一高取の鉄マンガン重石は初期に乱いては相当 低品位のものを使用していたが，その後選鉱技術の進歩 とともに高品位のものを( $\mathrm{WO}_{3} 65 \%$ 以上) 入手し得る様 になつた。「熔焼」による S, As の予備的除去は行つて いない。な粉砕は取扱上小ら湿式粉砕採用してい る。30hr 程度にて 200 mesh 以下にしている。

抽出：一一粉砕なるパルプはある程度水分除去後,

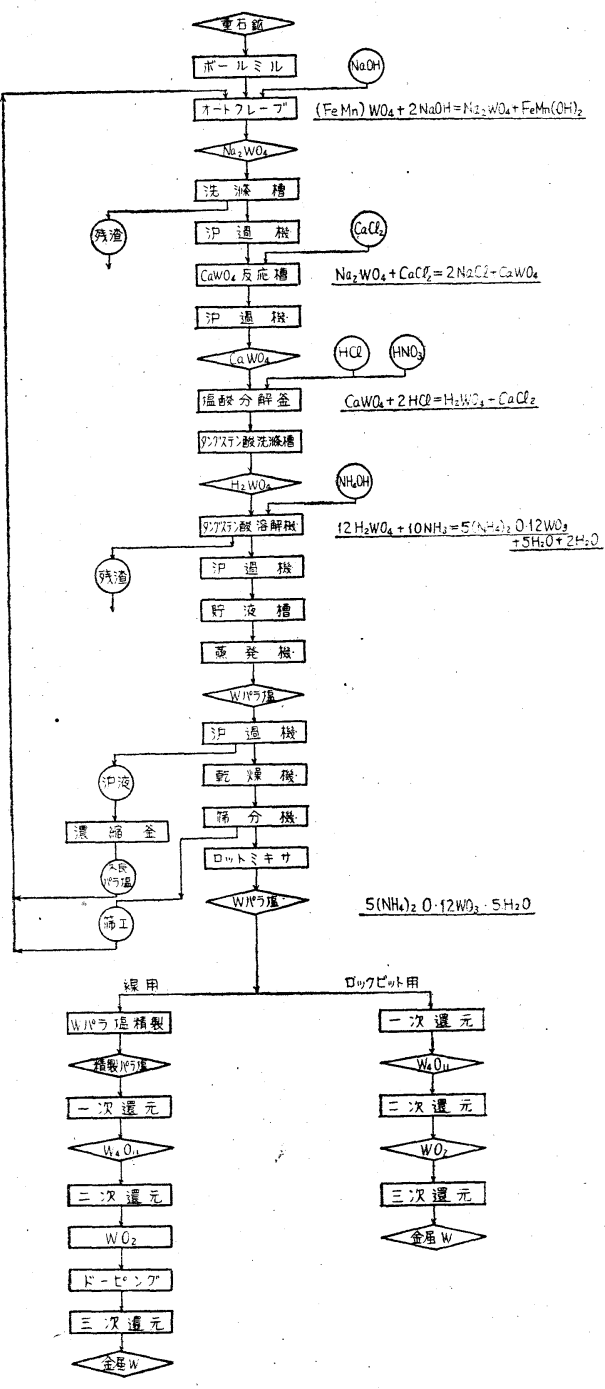

第1図タングステン製鍊工程 
装入してその $\mathrm{W}$ 含有量觉分析し濃苛性ソーメ゙で高圧高 温抽出资行つている。な抽出残椬は 5 回程度温水にて 攪汼洗滌して抽出歩留定上げるようにしている。

カルシュウム塩反応 :一一抽出液に塩化カルシゥム溶 液学添加し $\mathrm{CaWO}_{4}$ の沈搌堂得る。

塩酸分解: 一一湓酸分解釡は温水ジャケット付にして 約 $80^{\circ} \mathrm{C}$ 加熱して分解反応を促進させている。従来より 磁製釜を使用しているが刍裂事故をよく起し，また一操 作毎に釜危冷却させるための時間的損失があるので材質 を種々桱討しだが結局不純物の混入を避けるためにも磁 製のものを便用中である。反応温度, 塧酸の濃度等に不 手際を生ずるとタングステン酸水和物はコロイダル状に なり，その後の処理が困難になるので，この際塩酸に少 量の $\mathrm{HNO}_{3}$ 它加える。

タングステン酸洗涹：一洗滌水は洗滌中のコロイダ

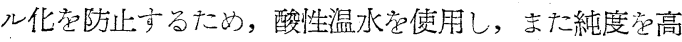
めるため, 純水を便用している。また洗滌能率觉上く卞 るための特殊の鹠玝装置觉付けている。

アンモニア溶解 : 一一この際生ずる溶液中のコロイメ゙ ル状の $\mathrm{Fe}(\mathrm{OH})_{3}, \mathrm{SiO}_{2}$ 等の不純物を除去するための沈 静㭙間の保持並びにその液の濾過方法を適切に行い，純 度の向上を計っている。

蒸発析出：一上記パシタングステン酸アンモンの精 製溶液の結晶析出させる條件，すなわち溶液の濃度，蒸 発温度, 攪拌方法, 母液の補給方法, 母液の保持時間, 冷却操作, 結晶の採取條件, 母液の残量等に対卞る條件 友一定に二保つ事により製品の純度維持，結晶体の粒度調 整を行つている。

メタル還元：一一管状式連続抵抗加熱還元炉を用いて 穿岩用テップ, 切削用テップ, 電球フィシメント用, 真 空管用等えれぞれの用途に応じて特有の還元條件てメタ 儿老作つている。

\section{4. 発展の経 緯}

\section{$4 \cdot 1$ 量的の問題}

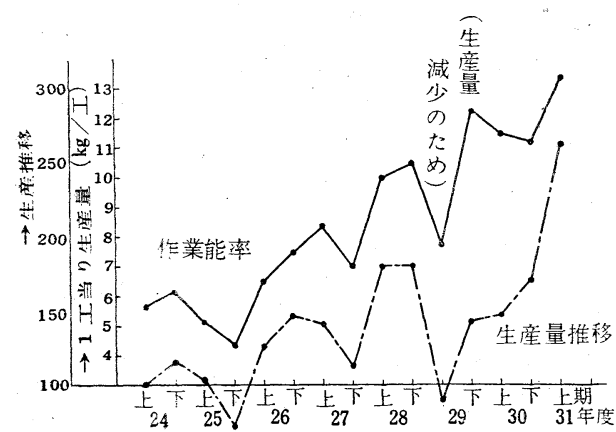

註 生產量推移は昭和 24 年上期を100こする。

第2図タングステンパラ塩生產量推移 並びに作業能率

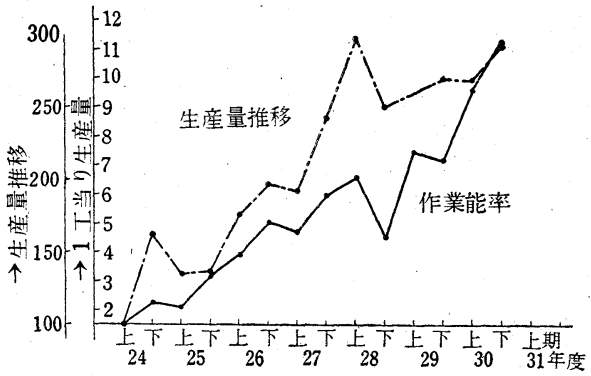

詰 生產量推移は昭和 24 年上期を100こする。

第3図 金属タングステン生產量推移 亚びに作業能率

生産量の推移は第 2 図, 第 3 困参照。試験期より漸次 増雇態勢に移行するにあたつての設備上の拡充, 改善, 機械化せる主なるものは次の通りである。

（1）天然ガスの利用 工場敷地内の鉱区にガス井 戸を掘りこれの利用によるコストの低下と計るととも に渴水期の電才不足による操業の支障を極力少なくする だめ，熱源として電力をほとんどがスに切換えた。

（2）増産に伴う副資材㥳料たるる薬品輸送の合理化 並びに設倩改善

a） $20 \mathrm{t}$ 塩酸タンク，硝酸及び塩酸のヘッドタンク， アンモニア水，塩化カルシウム溶液等の圧縮空気による 輸送。

b ）上記薬品つ睁槽並びに配管系統の整備及び計量槽 の設置による薬品節減。

（3）設䚚材質の改善而酸触並びに純度向上を期 する一助として逐次重点的に貯液槽, 濾過槽, パィブ等 㗊合成樹脂に切換えた。またパシ塩乾燥皿を金属製から 磁製に切換光た。

（4）パワ塩蒸発装置の改善 鉣山用テップ並ひにに 切削工具用デップ等用途に応じ原料パシ塩の性質苍变更 する必要があり，したがってえの蒸発装置もおのおの区 別し各一定の條件で例えは一定の濃度の一定量を一定の 温度にて蒸発析出せしめる方法学取つた。

\section{$4 \cdot 2$ 犋的の問題}

（1）製品純度の向上 結晶工程における精製方法 の改善により $\mathrm{SiO}_{2}$ 丈び $\mathrm{Fe}$ の微量存在をも許さない様

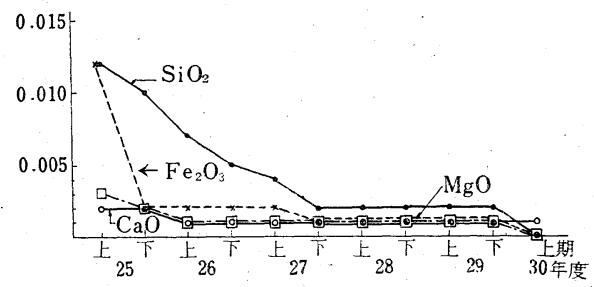

第4図 Wパラ塩純度表 
にした。

（2）イオン交換樹脂による純水装置を全面的に洗滌 及び溶解工程に利用純度の向上起計つた。As, P等の微 量の不純物の存在もW線に対し非常に影響を与え, 線の 加工性る悪くする事は周知の通りである。パシ塩純度表 は第4図のようである。

（3）成品品位の安定化

a ）28年度初期より品質管理手法をとり，化学純度並 びに粒度分布のデーターシートを作り工程のテェックを 行つた。

b ）蒸発工程の管理を徹底化することにより製品粒度 均一性を保持した。さらに製品に対するバシッキの巾を より少なくするため lot mixing 岩行つた。

（4）蒸発條件の検討改善 蒸発條件 (蒸発温度, 加 熱方法，その他）による粒度分布に対する影響を検討 し, 所要粒度のものを作る様にする。例えば攪汼蒸発結 晶法, 冷却結晶法, 低温蒸発結晶法等による製品区分を 行う。

（5）W線用メタルに対しては初めはWパラ塩它水素 還元により低級酸化物とし，これにドープ剂と称する例 えば $\mathrm{KCl}, \mathrm{SiO}_{2}, \mathrm{Al}_{2} \mathrm{O}_{3}$ 等を添加して線用Wメタル学製 造していたが，純度及び線の性質に特に影響するドープ 剤について種々検討した。その後水素還元の諸條件につ き検討を加え，天然がスを利用するがス加熱還元师を昭 和26年に新設し, 改めて根本的な検討を重ね, 昭和29年 に至つてさらに新しい製造方式の確立を見るに至つた。 改良の主要点は次のようである。

a) メタル粉末粒度分布

b) メタル粉末に添加するドープ剂の純度組成

線メーカー各社とも上記各項については公表されない が，粒度分布を規定值に収める要素は酸化物の種類，水 素還元に抢ける還元炬の温度分布，最高温度，時間，水 素の流量，管状炉に大る酸化物粉末のびろがり等であ 当。

（6）超硬用メタルに対してはパシW酸アンモンを原 料とし，2段，或いは 3 段 $\mathrm{H}_{2}$ 還元法に拠つた。

a）との間原料パンW酸アンモンとWメタルの粒度等 との関連を研究し，その還元條件等が眀らかにされWの 粒度分布並びに品位等が间上した。例えば原料タングス テン酸アンモンとW粒度の関係については次のようであ つた。

超硬質合金の主原料である金属タングステン粉末はパ シタングステン酸アンテン $\left[5\left(\mathrm{NH}_{4}\right)_{2} \mathrm{O}_{2} \cdot 12 \mathrm{WO}_{3} \cdot 5 \mathrm{H}_{2} \mathrm{O}\right]$ 启浄化した水素気流中で還元することによつて製造して いる。この場合に問題になるものは化学的純度及び物理 的性質特に粒度及びその分布状態である。化学的純度は 例えば炭化タン(WC) の配合に，粒子サィズは最終の合
金の性質に影響する。これらに及济す因子としては，一 般には「還元温度」,「原料の性質」,「水素流速」,「水素 蒸気圧」そその他還元炉の操作状態などが挙げられる。し たがつてこれらの因子を如何に制御して所望のタングス テン粉末を得るかが重要な問題である。次にこの中還元 温度，原料を要因として三元配置法にしたがつてある特 性值について実験した。

\begin{tabular}{|c|c|c|}
\hline$F_{1}$ & $\mathrm{~F}_{2}$ & A工程還元温度 \\
\hline$S_{1}$ & $\mathrm{~S}_{2}$ & B工程還元温度 \\
\hline & $\mathrm{M}_{2}$ & 原料口 \\
\hline
\end{tabular}

として水素流速，炉体等を一定としてある特性值につい て測定した。

\begin{tabular}{c|r|r|r|r}
\hline & \multicolumn{2}{|c|}{$\mathrm{F}_{1}$} & \multicolumn{2}{|c}{$\mathrm{F}_{2}$} \\
\cline { 2 - 5 } \cline { 3 - 5 } & \multicolumn{1}{|c|}{$\mathrm{S}_{1}$} & \multicolumn{1}{c}{$\mathrm{S}_{2}$} & $\mathrm{~S}_{1}$ & $\mathrm{~S}_{2}$ \\
\hline $\mathrm{M}_{1}$ & 2.9 & 2.5 & 2.7 & 3.7 \\
& 2.9 & 2.7 & 2.7 & 3.5 \\
$\mathrm{M}_{2}$ & 1.2 & 1.7 & 2.4 & 1.6 \\
& 1.1 & 1.7 & 2.5 & 1.7 \\
$\mathrm{M}_{3}$ & 2.1 & 3.4 & 2.4 & 3.5 \\
& 2.1 & 3.4 & 2.6 & 3.6 \\
\hline
\end{tabular}

分散分布表に緾めると次のようになる。

\begin{tabular}{|c|c|c|c|c|c|}
\hline 主 & & 自由度 & 不偏分散 & $\mathrm{F}$ 比 & 有鯰差 \\
\hline $\begin{array}{l}\mathrm{SS} \\
\mathrm{SM} \\
\mathrm{SF} \\
\mathrm{SS} \times M \\
\mathrm{SM} \times \mathrm{F} \\
\mathrm{SF} \times \mathrm{S} \\
\mathrm{SE} \\
\mathrm{ST}\end{array}$ & $\begin{array}{l}1.171 \\
7.386 \\
1.084 \\
1.686 \\
0.143 \\
0.033 \\
1.712\end{array}$ & $\begin{array}{r}1 \\
2 \\
1 \\
2 \\
2 \\
1 \\
14 \\
23\end{array}$ & $\begin{array}{l}1.171 \\
3.693 \\
1.084 \\
0.843 \\
0.072 \\
0.017 \\
0.122\end{array}$ & $\begin{array}{r}9.55 \\
30.23 \\
8.70 \\
7.50 \\
0.59 \\
0.01\end{array}$ & $\begin{array}{l}* * \\
* * \\
* \\
*\end{array}$ \\
\hline
\end{tabular}

これをなお確認するために実験号再度行い別の特性值に ついて行なつた。

\begin{tabular}{c|c|c|c|c}
\hline & \multicolumn{2}{|c|}{$\mathrm{F}_{1}$} & \multicolumn{2}{|c}{$\mathrm{F}_{2}$} \\
\hline & $\mathrm{S}_{1}$ & $\mathrm{~S}_{2}$ & $\mathrm{~S}_{1}$ & $\mathrm{~S}_{2}$ \\
\hline $\mathrm{M}_{1}$ & 4.60 & 4.23 & 4.44 & 4.11 \\
$\mathrm{M}_{2}$ & 5.27 & 4.76 & 5.00 & 4.65 \\
$\mathrm{M}_{3}$ & 3.60 & 3.44 & 3.52 & 3.50 \\
\hline
\end{tabular}

分散分布表に纒めると

\begin{tabular}{|c|c|c|c|c|c|}
\hline 主 & & 自由度 & 不偏分散 & F 比 & 有意差 \\
\hline $\begin{array}{l}\mathrm{SS} \\
\mathrm{SM} \\
\mathrm{SF} \\
\mathrm{S} \times \mathrm{M} \\
\mathrm{S} M \times \mathrm{F} \\
\mathrm{S} S \times \mathrm{F} \\
\mathrm{S} S \times \mathrm{F} \times \mathrm{M}\end{array}$ & $\begin{array}{l}0.252 \\
3.992 \\
0.039 \\
0.063 \\
0.016 \\
0.008 \\
0.004\end{array}$ & $\begin{array}{l}1 \\
2 \\
1 \\
2 \\
2 \\
1 \\
2\end{array}$ & $\begin{array}{l}0.252 \\
1.996 \\
0.039 \\
0.032 \\
0.008 \\
0.008 \\
0.002\end{array}$ & $\begin{array}{r}12.6 \\
99.8 \\
20 \\
16 \\
4 \\
4\end{array}$ & $\begin{array}{l}* * \\
* * \\
*\end{array}$ \\
\hline
\end{tabular}

以上のように実験としては同様な結果を得た。このよう に金属タングステンの睘元に際し，影響を及ぼす因子と して一般的には前述の通りであるが，この場合は特に操 業現場としてはA工程つ還元温度より $\mathrm{B} 工$ 程の還元温度 の方が粉末の特性にはより影響を与えているようであり 粉末の特性の制御に関してはB工程をよく管理すること によつて所望のものが得られる。 
b) 次に紫造條件並びに性質の違つた 2 種のパフタン グステン酸アンもンを還元條件を一定として還元した場 合Wの性犋は

\begin{tabular}{|c|c|c|c|c|c|}
\hline パラ塩 & $\mathrm{WO}_{3}$ & $\mathrm{SiO}_{2}$ & $\mathrm{FeO}$ & $\mathrm{CaO}$ & $\mathrm{MgO}$ \\
\hline $\begin{array}{l}\mathrm{A} \\
\mathrm{B}\end{array}$ & $\begin{array}{l}89.55 \\
89.27\end{array}$ & $\begin{array}{l}0.002 \\
0.002\end{array}$ & $\begin{array}{l}0.001 \\
0.001\end{array}$ & $\begin{array}{l}0.001 \\
0.001\end{array}$ & $\begin{array}{l}0.001 \\
0.001\end{array}$ \\
\hline \multicolumn{6}{|c|}{\begin{tabular}{l|l|l|l} 
& \\
パラ塭 & $\mathrm{NH}_{4}$ & $5\left(\mathrm{NH}_{4}\right)_{2} \mathrm{O}$ & $\mathrm{H}_{2} \mathrm{O}\left(5 \mathrm{H}_{2} \mathrm{O}\right)$
\end{tabular}} \\
\hline$\stackrel{\mathrm{A}}{\mathrm{B}}$ & \multicolumn{2}{|c|}{$\begin{array}{l}5.78 \% \\
5.76 \%\end{array}$} & $\begin{array}{l}8.34 \% \\
8.32 \%\end{array}$ & & $\begin{array}{l}2.83 \% \\
2.84 \%\end{array}$ \\
\hline
\end{tabular}

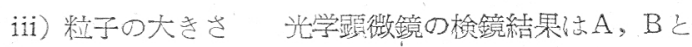
もに活同椂な粒度分布及び粒度等有し大きさの比較は 出来ない。たた見脚比重は A $2.4 \mathrm{~g} / \mathrm{cc}$ ，B $2.6 \mathrm{~g} / \mathrm{cc}$ あつた。

このような2種のパラタンダステン酸アンモン筧次の 還元條件で還元した。

一次還元, 温度 $570^{\circ} \mathrm{C} \times 1.5 \mathrm{hr}$ 水素 $15 \mathrm{l} / \mathrm{min}$

二次還元，還元温度，時間 $880^{\circ} \mathrm{C} \times 15 \mathrm{hr}$ 水素 $30 \mathrm{l} / \mathrm{min}$

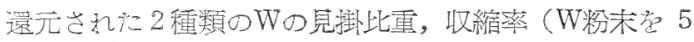
$\mathrm{t} / \mathrm{cm}^{2}$ て圧縮し $1,300^{\circ} \mathrm{C} \times 1 \mathrm{hr}$ で水素中で焼結した) $\mathrm{O}_{2}$ $\%$ ，开均粒度 (光電比色言)，顕徽鏡，電子顕微鏡等につ いて測定し比較した。

\begin{tabular}{|c|c|c|c|c|c|}
\hline \multirow{2}{*}{\multicolumn{2}{|c|}{$\begin{array}{c}\text { パラ塩の見掛比重 } \\
\mathrm{g} / \mathrm{cc}\end{array}$}} & \multicolumn{4}{|c|}{ W の測定值 } \\
\hline & & 見掛此重 & $\mathrm{O}_{2} \%$ & $\begin{array}{c}\text { 收 緥 率 } \\
(\%)\end{array}$ & $\begin{array}{c}\text { 平均粘底 } \\
(\mu)\end{array}$ \\
\hline$\stackrel{\mathrm{A}}{\mathrm{B}}$ & $\begin{array}{l}2.4 \\
2.6\end{array}$ & $\begin{array}{l}3.0 \\
3.5\end{array}$ & $\begin{array}{l}0.13 \\
0.05\end{array}$ & $\begin{array}{r}14 \\
9\end{array}$ & $\begin{array}{r}6 \\
15\end{array}$ \\
\hline
\end{tabular}

W粉末学 Cu-Wetting 法によりみたWの粒子は写真1 の霣微鏡写真に示す。

さらに電子顕微鏡写真は写真 2 の様である。

以上のようにタ゚ラタングステン酸アンモン存還元して Wを製造するときにパラタングステン酸アンモンの相違 によつて同一條件で製造されるWの性質は箸しく異なる ことが解る。したがつて原料のバラッキについては原料 整造工程に対してさらに改善を加え，かつ原料のある特 牡値について十分管理する必要が認められた。
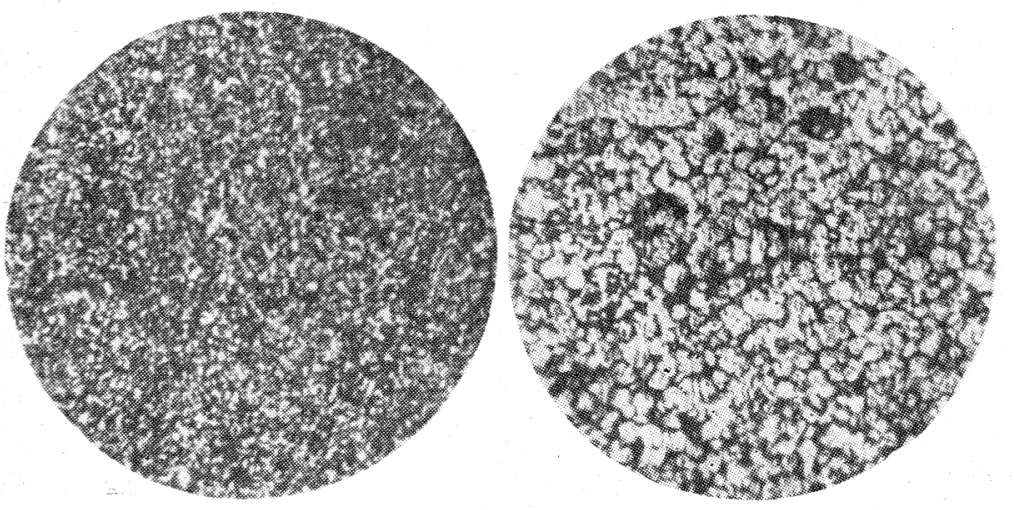

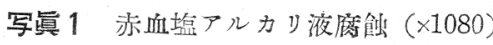
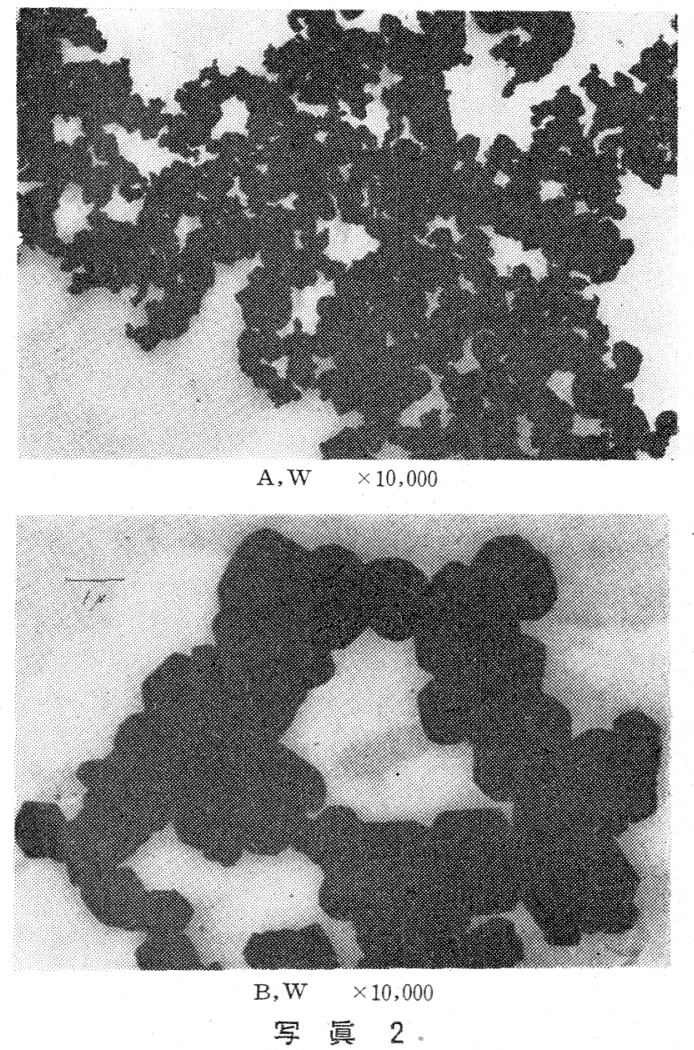

c）タングステン゙線並びに超硬合金原料のWパワ塩は 板状パシ塩並びに釬状パシ塩が考えられる。おのおの於 個に板状パシ塩を同一條件で水素䁗元してW㛊末之した 場合粒子の大きさに如何なる差異があるか研究検討し た。

i ）昆微鏡によ方還元過程の外形観察では板状結晶の 方が自然分裂する傾间がある。

ii）ローヌップ節分機の震動並ひに衝撃による $W_{\text {上 }}$

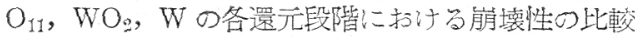
で $\mathrm{W}_{4} \mathrm{O}_{11}$ てでは明らかに板状結晶の方が崩壊し易 く，この美ま $\mathrm{WO}_{g} ， \mathrm{~W}$ 迄現われ綜合的に板状パー 塩より還元したW粉末の方方 崩㙥し易小様である。

iii）弱い衝撃に上ると針状結晶 の方がW粉末心崩壊し難く相 当数於原形を业动ている様て あ⿳。

の如き観察右得た。近時さらに還 元作業の均紊化老企図して作業方 式の改善党行い一方最終製品之の 関連の追及も進几て品質標潗も確 立し、こく安定した生産状態続 けている。 


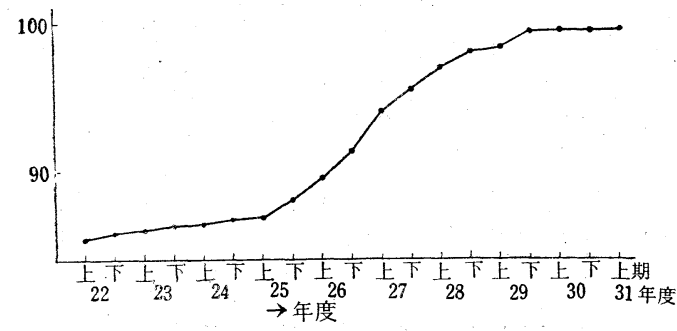

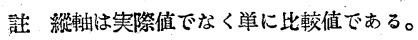

第 5 図製鍊实收向上図表（Wパラ塩）

\section{$4 \cdot 3$ 操業上の問題}

（1）不良原料（不良焼結テップ，不良W線㞒）繰返 原料等の再生利用による歩留向上をなした。

（2）示ールミル粉砕時間と抽出率との関係並びにこ れに伴う $\mathrm{NaOH}$ の便用節減すなわち粉碎時間を適正に 行う事により抽出率を向上させ $\mathrm{NaOH}$ の使用節減を計 つた。かくのように free アルカリの量を減少せしむる 事により，次の工程における $\mathrm{CaCl}_{2}$ の使用量の節減を 計り得られた。

（3）イオン交換樹脂の寿命の延長を計る。イオン交 換樹脂の寿命は 3,000 サイクルと言われているが，これ は原水から来当浮遊物，鉄粉等が多いと相当短かくなる のて原水に対する除濁装置を設ける事により一層寿命を 延ばし得た。

(4) 生成物の洗㴪能率の向上をなした事 $\mathrm{CaWO}_{4}$, $\mathrm{H}_{2} \mathrm{WO}_{4}$ 等反応生成物はその反応の際の溶液の濃度, 温 度，操作により粒度の粗いもの，細かいものが生じ，洗 滌に難易が生ずるのてこの点を実験データにより改善し 粗粒度のものを作り，その後の操作を容易ならしめた。

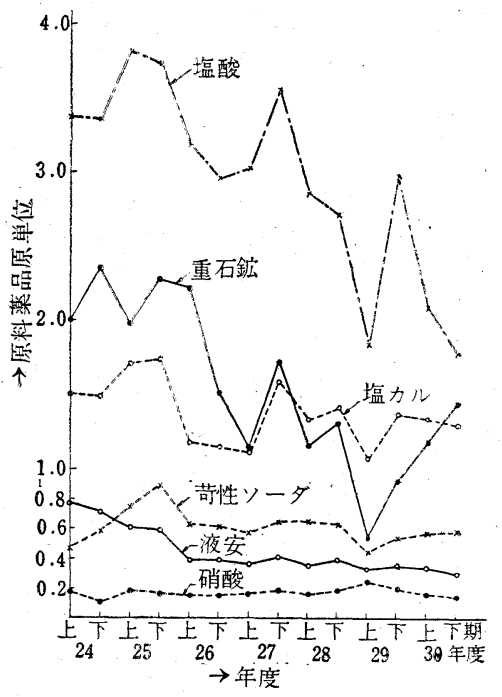

第 6 図

製鍊归用 薬品類原 単位推移 $\left(\begin{array}{c}W \text { パラ㙁 } \\ \mathrm{t} \text { に対し }\end{array}\right)$

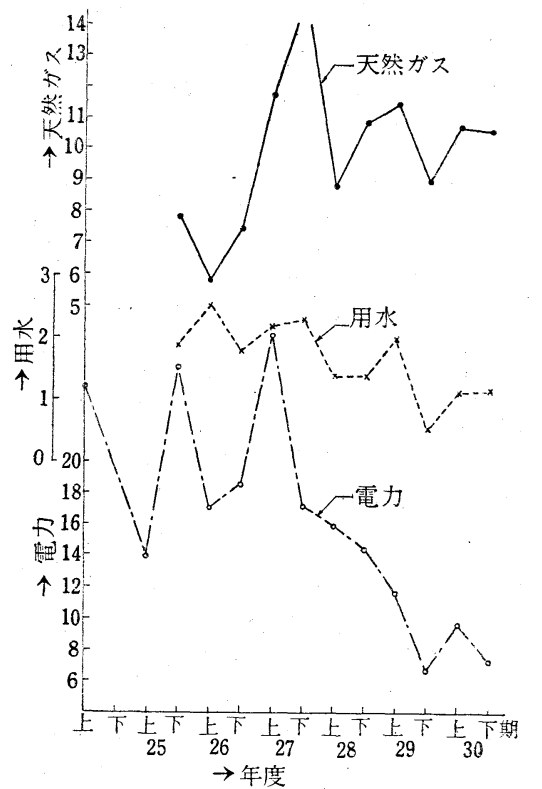

第 7 図

各種 原単位推移

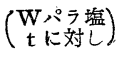

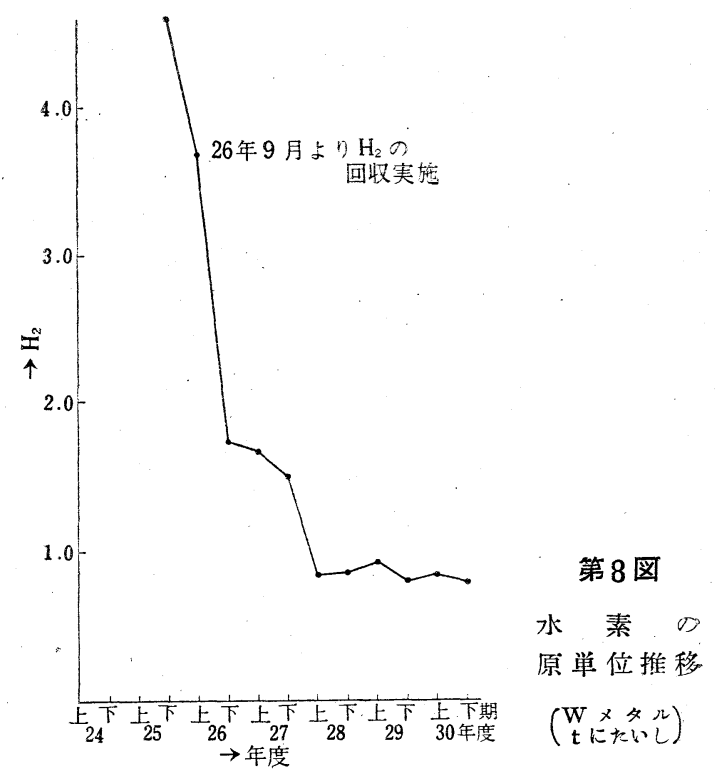

（5）各工程における仕掛品の適正配置 工程の多 い作業にあつては各工程におうる作業量並びに作業速度 より正確なる工程管理図を作成し，工程と工程との継ぎ をスムーズにする。適正な能力を持つた設備を置くと同 時に調整用の仕掛品並ひに装置内残量を計算し常にとの 適正基準の任掛品を維持する事により，作業能率化を計 りまた最も能率的なる人員配置も得られる事となる訳で ある。

\section{$4 \cdot 4$ 原佂低減上の問題}

(1) 作業能率 第 2 圀, 第 3 困の通り。 
（2）原単位 第 6 図, 第 7 目, 第 8 図の通り。

製品の $1 \mathrm{~kg}$ 当りの使用薬品量並びに補助原料である天 然ガ ,用水,電力の使用量等の変化を記載したものであ る。なお毎期の平均月当り生産量にて実績使用量を除い たものであるから各工程における仕掛品の変動, 作業量 の多少, 生産方式の改廃, 鉣石品位の変化等のため見掛 上の原単位を表わしているものであるが，作業上の変遷 傾向が掝めるものと思われる。

\section{5. 今後の 問 題}

昨年当社はドィソPeutehe Edel Stahl Werke 社の 超硬合金 Titanit の製造技術を導入し今後ますます超硬 質合金の技術的発展に努力しているがこれによると原料 の成分，規格等が極めて厳密である。これに対応して 現在諸種の製錬技術設㣁の再整㣁, 検定設㣁, 機器の輸 大，新設等を行いつつある。

\section{モリブデン製錬の部}

\section{6. 現在の作業方法}

Mo 線觉䑽作する事となり，この原料としては当社山 佐鉱山（島根県）の輝水鉛鉣を使つて中間製品として， Mo パシ塩を製鍊している。その製鍊方法の概要は次の ようである。

焙燒：一一輝水鉛鉣を乾燥粉碎して外熱式アンンダム 管の中で焙暁する。温度は $600^{\circ} \mathrm{C}$ 程度である。低いと

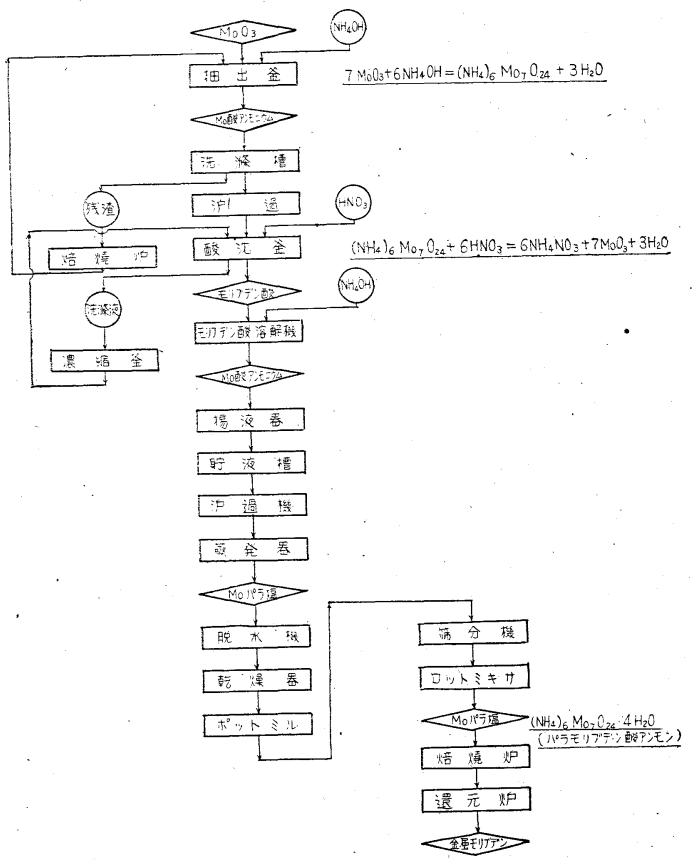

第9図モりブデン
Mo 鉣石成分

\begin{tabular}{|c|c|c|c|c|c|c|c|c|c|}
\hline \multirow[b]{2}{*}{ 䡣水鉛鉱 } & 試料 & Mo & $\mathrm{Fe}$ & $\mathrm{SiO}_{2}$ & $\mathrm{Cu}$ & $\mathrm{CaO}$ & MgO & $\mathrm{Al}_{2} \mathrm{O}_{3}$ & $\mathrm{~s}$ \\
\hline & $\frac{1}{2}$ & \begin{tabular}{|}
45.56 \\
30.32
\end{tabular} & $\begin{array}{r}1.96 \\
10.20\end{array}$ & $\begin{array}{l}13.26 \\
21.36\end{array}$ & $\begin{array}{l}0.06 \\
0.50\end{array}$ & 0.37 & 0.28 & 0.46 & 32.78 \\
\hline \multirow[b]{2}{*}{$\mathrm{MoO}_{3}$} & 試料 & Mo & $\mathrm{Fe}$ & $\mathrm{SiO}_{2}$ & $\mathrm{Cu}$ & $\mathrm{CaO}$ & $\mathrm{MgO}$ & $\mathrm{Al}_{2} \mathrm{O}_{3}$ & $\mathrm{~s}$ \\
\hline & $\frac{1}{2}$ & $\begin{array}{l}63.55 \\
53.41\end{array}$ & $\begin{array}{l}1.003 \\
4.12\end{array}$ & $\begin{array}{l}2.190 \\
8.92\end{array}$ & $\begin{array}{l}0.117 \\
0.39\end{array}$ & $\begin{array}{l}0.190 \\
0.225\end{array}$ & $\begin{array}{l}0.037 \\
0.149\end{array}$ & $\begin{array}{l}0.162 \\
0.162\end{array}$ & $\begin{array}{l}0.109 \\
1.808\end{array}$ \\
\hline
\end{tabular}

充分にSがとばない。また時間がかかる。温度が高いと焼 結され或いは晨華して久減となる。な放空気（酸素）の 供給を適当に行う事が特に大切で，このためには時々原 料を攪拌する事，また空気の流速を早くすると原料粉末 の久減を起す事ともなる。この焙烓操作の不出来は直ち に次の工程の抽出率に影響を与えるものである。現在は 山佐鈗山の休止並びに焙焼費の非能率コスト高のために 焙焼工程を不必要とする原料すなわち $\mathrm{MoO}_{3}$ に切り換元 ている。ただし抽出残渣に対する再処理並びに繰返し原 料に対する再処理の場合には焙焼を行う。

抽出：一- $\mathrm{MoO}_{3}$ を液安より作つた安水に溶解する。

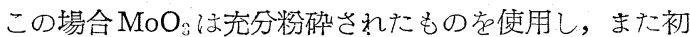
めの間だけ反応促進のため抽出釜の外部から加熱してゃ る。この抽出液尼濾過して次の工程に送る。

酸沈：一一抽出液中には銅，その他の不純物を溶解し ているから硝酸を滴下させてもリブデン酸の白色沈澱を 作りデカンテーションして銅粉を除去す。この場合上記 抽出液と硝酸との反応させる操作が非常に微抄であり生 成モリブデン酸がコロィメ゙ル状になつたり，或いは沈静 洗滌され易い粗いものが出来たりするものである。すな わち抽出液の濃度, 硝酸の濃度, 温度並びに硝酸の添加 する速度，䚑拌方法等により左右されるものである。

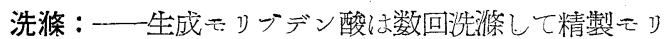
ブデン酸を作り再びアンこニア水に溶かして精製パンモ リブデン酸アンモン溶液を作る。な抢もリブン酸沈洪を 完全にするために少量の硝酸アンモンを大れた洗滌水觉 使用する。

蒸発析出：一一再溶解した溶液には鉄，えの他が残る からこれを除くために加熱酸化して沈洪学作り濾過して 然る後, 蒸発析出を行うのである。もちろん不純物の 濃縮混大を避けるため母液を適量残して結晶採取を打切 る。

乾燥・フルイ分：一この結晶を乾燥，フルイ分後 lot mixing して成品の均一性を保つている。

炉熱：一還元工程に対する事前操作であつて Mo ஃ゚ シ塩をルツ亦中で空気を断って天然がスて灼熱すると $\mathrm{Mo} \mathrm{O}_{2}$ を主体とした種々の酸化度を有する $\mathrm{Mo}$ 酸化物 が得られる。これが次の水素睘元において適切な粒度を 持つた Moメタルを作る事に好都合な條件となるのであ る。 


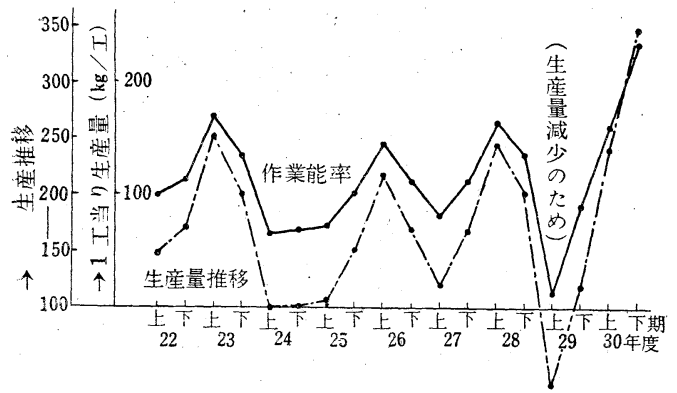

註 生虚量推移结略和 24 年上期学 100 こす。

第10図モリブデンバラ塩の生產量と作業能率 (Mo パラ塩)

還元：- - $2 " \% \times 4 \mathrm{~m}$ のガ ス加熱炉 2 炬在使用して行 つていたが，最近単炉方式に切換えた。

\section{7. 発展の経緯}

\section{$7 \cdot 1$ 量的の問題}

生座量の推移は第10図参照, な㧍増産に伴う設備の改 善，拡充を行つた主なものは次の通り。

(1) $\mathrm{MoS}_{2}$ 焙焼洰の改良単炬方式を連続押达方式 に切り換え，焙焼能率が倍になつた。な抢均一なる 焼鉱が得られる様になつた。

（2）焼鉱の粉砕設倩の取付抽出歩留存向上させる ため焼鉱を粉砕京ることにより歩留が琽しく向上し た。

（3） 天然ガスの利用 抽出加熱装置並びに蒸発装置 を従来の電気から天然がスに切撸えた。

（4）蒸発装置の能率化従来の磁製釜を金属製に切 換え蒸発速度を早める事になつた。

（5）設㒂容量の堌大化による能率向上並びに品質安定

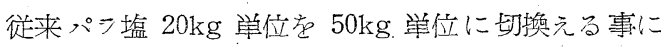
した。

（6）設䚚材質の合成禧脂の切门換え。

\section{$7 \cdot 2$ 诈的の問題}

(1) 純度の向上

i ）イオン交換樹脂による純水装置の利用

ii）酸沈工程に抢ける $\mathrm{Cu}$ 粉の除去の徹底化

iii）原料である $\mathrm{MoS}_{2}$ 在高品位の $\mathrm{MoO}_{3}$ に切引換え 步留の向上並びに純度の向上を計つた。
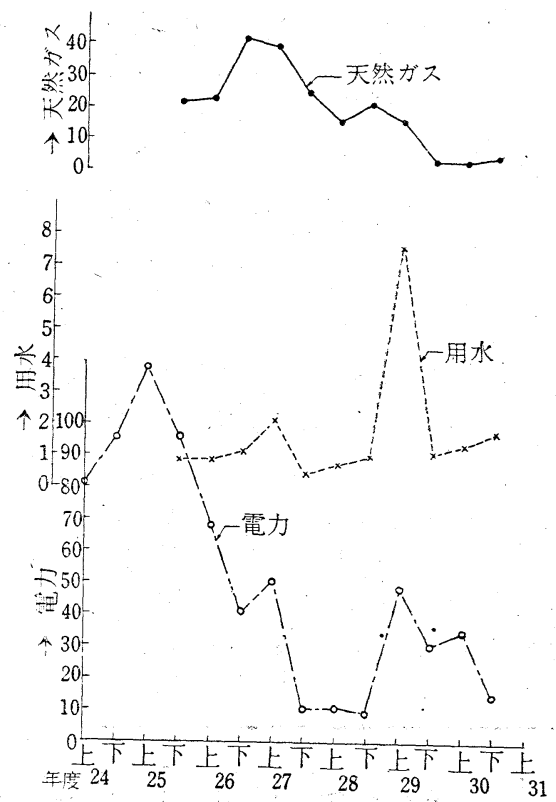

第11図 各種原単 位推移

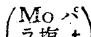

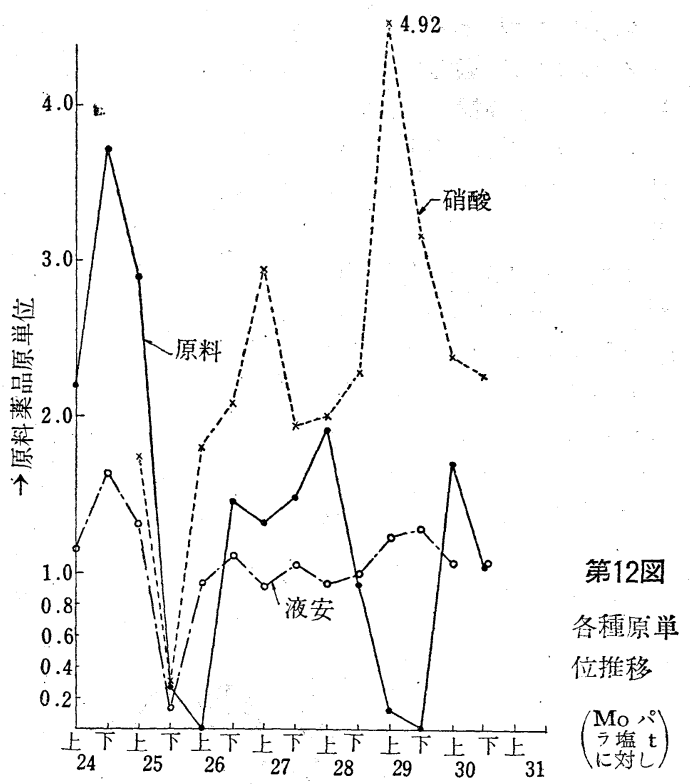

iv）蒸発工程に掠け兮第一鉄塩の除去方法の改良, Mo パン塩の純度表は下表のようである。

$7 \cdot 3$ 操業上の問題

Mo パラ塩純度表

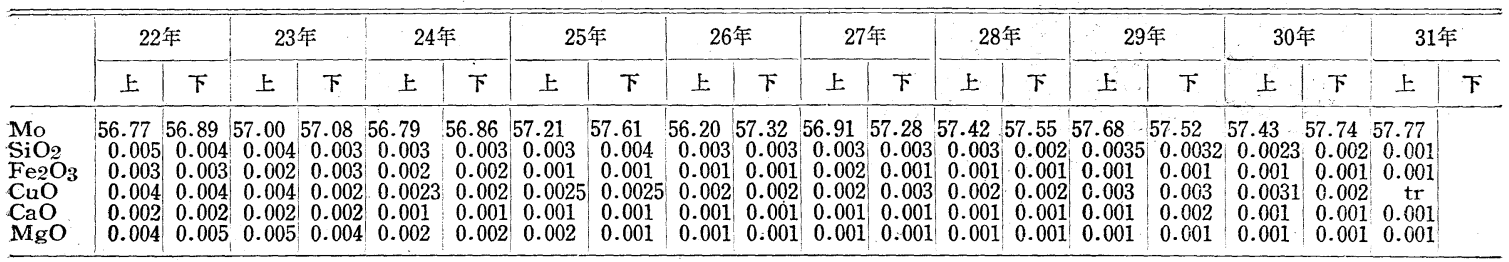


(1) Mo 線屑, 繰返原料 (抽出残渣等) の再生利用 による歩留问上。な怙現在試作中の昇華法によりて得

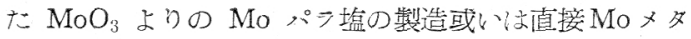
ルへの還元等による不純物, $\mathrm{Cu}$ の完全除去並びにェス トの引下げに今後の期待老かけている。

（2）還元师の改造 ほとんどW線用メダルと同様 の方法て水素還元によりメタル製造した。Mo 酸化物 をメタルに還元方名温度は $W$ が約 $800^{\circ} \mathrm{C}$ でるに対し， Moは $900^{\circ} \mathrm{C}$ であるためW の様にスデンレスパィプ 在還元炬管として使用出来ずアンンメ゙ム管にMo線存巻 き吙温范約 $1,000^{\circ} \mathrm{C}$ とて連繶睘元した。この場合も適 当な粒度分布と純度を確保するために努力したが四和 27 年, 従来の水素還元法によつて, 中間酸化物在裴造方当 ことをやめて天然がス起利用してMoパン塩友ルリ示に 入れ空気在断つて加熱 $\left(700^{\circ} \mathrm{C}\right.$ 位 $)$ 乙, $\mathrm{MoO}_{\mathrm{a}}$ 在主成分之

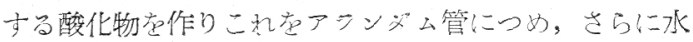

素炉に収め杽温還元後泠却して取り出すいわゆる単炬法 に切り換えてメタル粉未を作る新しい方式を確立した。 これによつて従来の歩留は飛躍的に向上し, 各ロットと も全部線用として処理するまていなつた。

\section{$7 \cdot 4$ 原価低減上の問題}

(1) 作業能率 第10図の通门。

(2) 原単位第11図, 第12図の通り。

\section{8. 今後の問題}

昭和29年未真空管用として高品位のMo 線の需要があ り上記の各工程に再検討灰加えつつ今日に至つている。 な打現在試験中の舁華法によつて得た $\mathrm{MoO}_{2}$ から $\mathrm{Mo}$

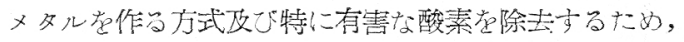

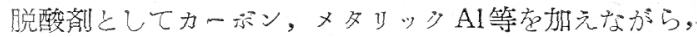

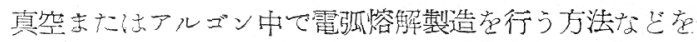
研究中である。

\section{Kett赤外線含水率計}

本装置は天科上の試料を赤外線う ンプで照射し，適温で迅速な加熱効 果によつて短時間に完全乾燥試料之 なし，その時の減少画量虚直らに水 分百分率で科量指示するものであ 尚。

写其の F-2 型は1 回に多量の辀 料(100 200g) 家測定し得点, 拉 よび項文で操作が簡易なため，誰に でも便える点で，鉱業万面の現暏间 きな水分計として適当な性格在具元 ているものと思う。

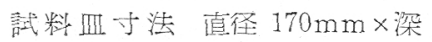
さ $15 \mathrm{~mm}$

測定水分算囲 0 ～100\%全域

$$
\begin{array}{ll}
\text { 測定所要時間 } & 10 \sim 20 \text { 分 } \\
\text { 精 } & \text { 度 } \\
0.2 \%
\end{array}
$$

赤外線ランフ $185 \mathrm{~W} \times 3$ 個

電源 交流 $100 \mathrm{~V}$

寸法, 雷量 $40 \times 45 \times 20 \mathrm{~cm} 8 \mathrm{~kg}$ 棈造：上四天科友反射板付のケ一大 に納め，雷镭血存大きく定め，試料 且上方に 3 個の赤外線シンブを号つ て熱源としている。乾燥の終了は, 天科の傾斜運㖶が止宗ることによつ て平衡指釬が静止するふら，容易に 観察することが出来公。その時, 内 部の天科に取付けて市当ライダ一在 外部のッマミで操作(攂動)して天和 学平衡さ垃ると，ライダーに付加乙

てある指釬加

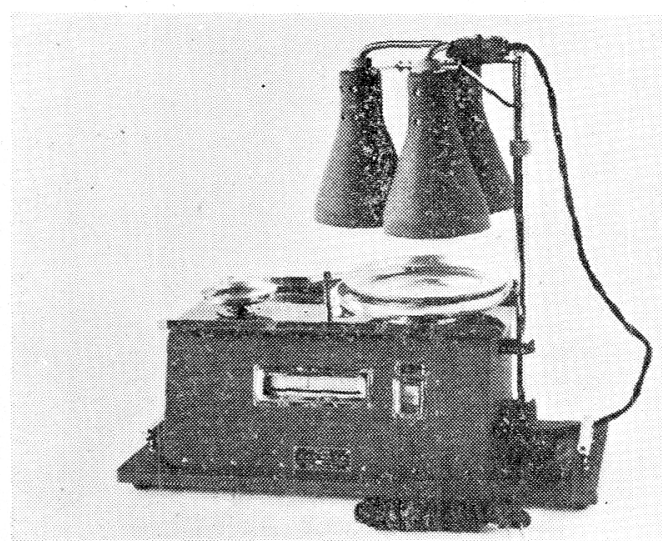

（1）加熱乾燥の可能な物澌反ら 何んでも測定出来る。

（2）加熱温度はランプの舁降に よつて自在に変えうる。最高温度は $200^{\circ} \mathrm{C}$ 以上であるから，熱に強い物 質の場合には，温度在上げて測定時 間荧短縮与ることが出来る，

（3）天科室ケースは，只の上面 に䇥間觉隔てて反射板它設けたこと によつて，完全に加熱ふら遮断され ている。したがつて連続使用によつ て天科の指度変化は全くない。

（4）水分指示は軽いライダーの 搖動で行うから，指度拡大率が大き 4.

（5）測定は天科の水平衡点で行 われるから, 傾斜位置で測る方法の ような摩擦愦差がない。

\section{特長}

（1）滴温で涴全乾燥虎行つた結 果の電量变化在值知にのまま表示 主るから，承分測定の標集法，すな わち恒温辆燥器之化学天科による測 定法の結果之泉々一致する。

（2）操作が籀単で, 作動が確実 であるふら，䛊差要素が少なく，故 障も起きない。

（4）付属の雷鍕を用心て, 指示 の確等簡篻に点検すること加出来 るので，便用上何等の不安がない。

(三和電気科学研究所提供) 